\title{
New drilling of the early Aptian OAE1a: the Cau core (Prebetic Zone, south-eastern Spain)
}

\author{
Pedro Alejandro Ruiz-Ortiz ${ }^{1}$, José Manuel Castro ${ }^{1}$, Ginés Alfonso de Gea ${ }^{1}$, Ian Jarvis ${ }^{2}$, José \\ Miguel Molina ${ }^{1}$, Luis Miguel Nieto ${ }^{1}$, Richard David Pancost ${ }^{3}$, María Luisa Quijano ${ }^{1}$, Matías Reolid ${ }^{1}$, \\ Peter William Skelton ${ }^{4}$, and Helmut Jürg Weissert ${ }^{5}$ \\ ${ }^{1}$ Jaén University, CEACTierra, Campus Universitario, 23071, Jaén, Spain \\ ${ }^{2}$ Kingston University London, Department of Geography and Geology, Kingston upon Thames KT1 2EE, UK \\ ${ }^{3}$ Organic Geochemistry Unit, School of Chemistry and Cabot Institute, University of Bristol, \\ Bristol BS8 1TS, UK \\ ${ }^{4}$ The Open University, Walton Hall, Milton Keynes, MK7 6AA, UK \\ ${ }^{5}$ ETH Zürich, Dep. Earth Sciencies, Sonneggstrasse 5, 8092 Zürich, Switzerland \\ Correspondence to: Pedro Alejandro Ruiz-Ortiz (paruiz@ujaen.es)
}

Received: 18 February 2016 - Revised: 10 June 2016 - Accepted: 20 July 2016 - Published: 10 August 2016

Abstract. The Cretaceous was punctuated by several episodes of accelerated global change, defined as Oceanic Anoxic Events (OAEs), that reflect abrupt changes in global carbon cycling. The Aptian Oceanic Anoxic Event (OAE1a; $120 \mathrm{Ma})$ represents an excellent example, recorded in all major ocean basins, and associated with massive burial of organic matter in marine sediments. The OAE1a is concomitant with the "nannoconid crisis", which is characterized by a major biotic turnover, and a widespread demise of carbonate platforms. Many studies have been published over the last decades on OAE1a's from different sections in the world, and provide a detailed C-isotope stratigraphy for the event. Nevertheless, new high-resolution studies across the event are essential to shed light on the precise timing and rates of the multiple environmental and biotic changes that occurred during this critical period of Earth history.

Here we present a new drill core recovering an Aptian section spanning the OAE1a in southern Spain. The so-called Cau section was drilled in the last quarter of 2015. The Cau section is located in the easternmost part of the Prebetic Zone (Betic Cordillera), which represents platform deposits of the southern Iberian palaeomargin. The lower Aptian deposits of the Cau section belong to a hemipelagic unit (Almadich Formation), deposited in a highly subsident sector of the distal parts of the Prebetic Platform. Previous work on the early Aptian of the Cau succession has focused on stratigraphy, bioevents, C-isotope stratigraphy, and organic and elemental geochemistry. A more recent study based on biomarkers has presented a detailed record of the $p \mathrm{CO}_{2}$ evolution across the OAE1a (Naafs et al., 2016). All these studies reveal that the Cau section represents an excellent site to further investigate the OAE1a, based on its unusually high sedimentation rate and stratigraphic continuity, the quality and preservation of fossils, and the well-expressed geochemical signatures.

\section{Introduction}

The occurrence of time intervals of enhanced deposition of organic matter $(\mathrm{OM})$ during the Cretaceous, defined as Oceanic Anoxic Events (OAEs), reflect abrupt changes in global carbon cycling (i.e. Erba, 1994; Beerling and Royer, 2002; Dumitrescu et al., 2006; Jenkyns, 2010). The Aptian Oceanic Anoxic Event (OAE1a; about $120 \mathrm{Ma}$ ), represents one of the best examples of these events, with a global distribution recorded in all major ocean basins, and is associated with massive burial of organic matter in marine sediments. The OAE1a is concomitant with the "nannoconid crisis", which represents an episode of major biotic turnover (Erba, 1994; Erba et al., 2010), and is coincident with a widespread demise of carbonate platforms (Föllmi, 2012). The event has 


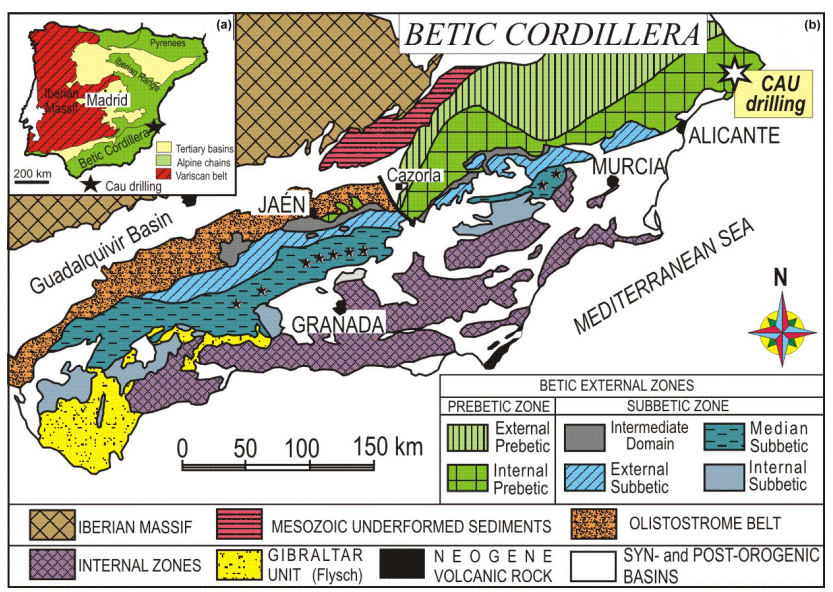

Figure 1. Location of the Cau section in the northern part of the Betic Cordillera in SE Spain. (a) National. (b) Regional geological setting.

been linked to a marked increase in sea-surface temperatures and $p \mathrm{CO}_{2}$, resulting in major changes in marine and terrestrial environments and biotas (Erba et al., 2015; Naafs et al., 2016). Much research has been done on the OAE1a from different sections across the world over the last decades (Schlanger and Jenkyns, 1976; Jenkyns, 1980; Arthur et al., 1985, 1990). A classic reference defining of the C-isotope stratigraphy of the event by Menegatti et al. (1998), has been widely applied by subsequent studies (see compilation in Erba et al., 2015). Among the most relevant questions are the origin of the carbon cycle perturbation, its potential association with submarine volcanic outgassing from the Ontong Java and other submarine plateaus, and the role of methane release from gas hydrates (Larson and Erba, 1999; Tejada et al., 2009). Although much multi-disciplinary research has been done on different OAE1a sections, additional high-resolution studies across the entire event will be crucial to shed light on the precise timing and rates of change of the different environmental and biotic perturbations that occurred.

In order to perform high-resolution studies, drill cores generally represent the best option. Previous coring of the OAE1a, with successful scientific results has been performed in two reference sections: the Cismon Apticore in northeastern (NE) Italy (Erba et al., 1999), and more recently, at La Bédoule in south-eastern (SE) France (Flögel et al., 2010; Lorenzen et al., 2013).

\section{The Cau section}

The Cau section is located in the NE portion of Alicante province (Fig. 1) and records deposits of the distal parts of a shallow carbonate ramp. In this setting, hemipelagic sedimentation took place during the late Barremian to late Aptian, before a progradational episode led to the deposi-

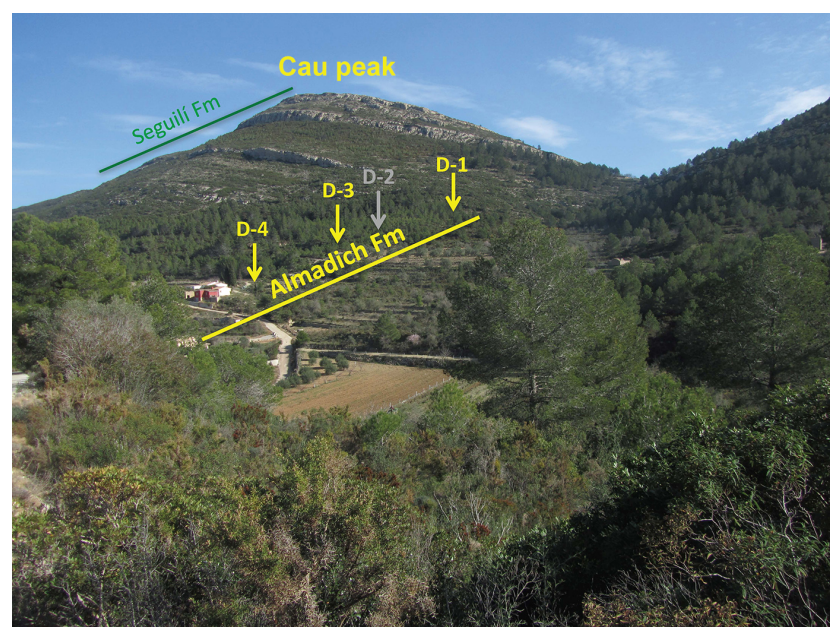

Figure 2. Panoramic view of the Cau section showing the position of the Almadich and Seguilí formations and the three drilling sites, D-1, D-3, and D-4, realized in 2015. Planned drill D-2 (in grey) was considered to be unnecessary and has not been performed.

tion of shallow platform carbonates during the latest AptianAlbian. The upper Barremian to upper Aptian is represented by the Almadich Formation (Fig. 2), made up by hemipelagic marls and marlstones with ammonites, planktonic foraminifers, and calcareous nannofossils. The shallow platform carbonates (above) are represented by the Seguilí Formation (Fig. 2). Figure 3 shows the lithostratigraphy, biozones, and bioevents of the Almadich Formation in the Cau section, along with bulk carbonate and total organic matter stable carbon isotopes (de Gea et al., 2003; Quijano et al., 2012; Naafs et al., 2016). A thick horizon of black marls corresponding to the OAE1a occurs in the lower part of the Leupoldina cabri planktonic foraminifer biozone, the Hayesites irregularis nannofossil biozone. The nannoconid crisis (Fig. 3) has been also recognized in this section (Aguado et al., 1999; de Gea et al., 2003). The stratigraphy, biostratigraphy, and isotope chemostratigraphy of the Cau section have been presented in detail in previous publications from outcrop studies made at a decimetre to metre scale (Aguado et al., 1999; de Gea et al., 2003; Castro et al., 2008; Naafs et al., 2016).

\section{The Cau drilling}

The OAE1a is represented in the Cau section by about $40 \mathrm{~m}$ of black and dark grey marls and marlstones. The expanded nature of the section along with its well-preserved palaeontological and geochemical records constitute the basis for its selection as the best OAE1a section in the Betic Cordillera, and thus provides one of the best known OAE1a records worldwide. The Cau drilling has been undertaken to allow very detailed sampling of the cores, in order to further increase the resolution attained from the outcrops. The authors 


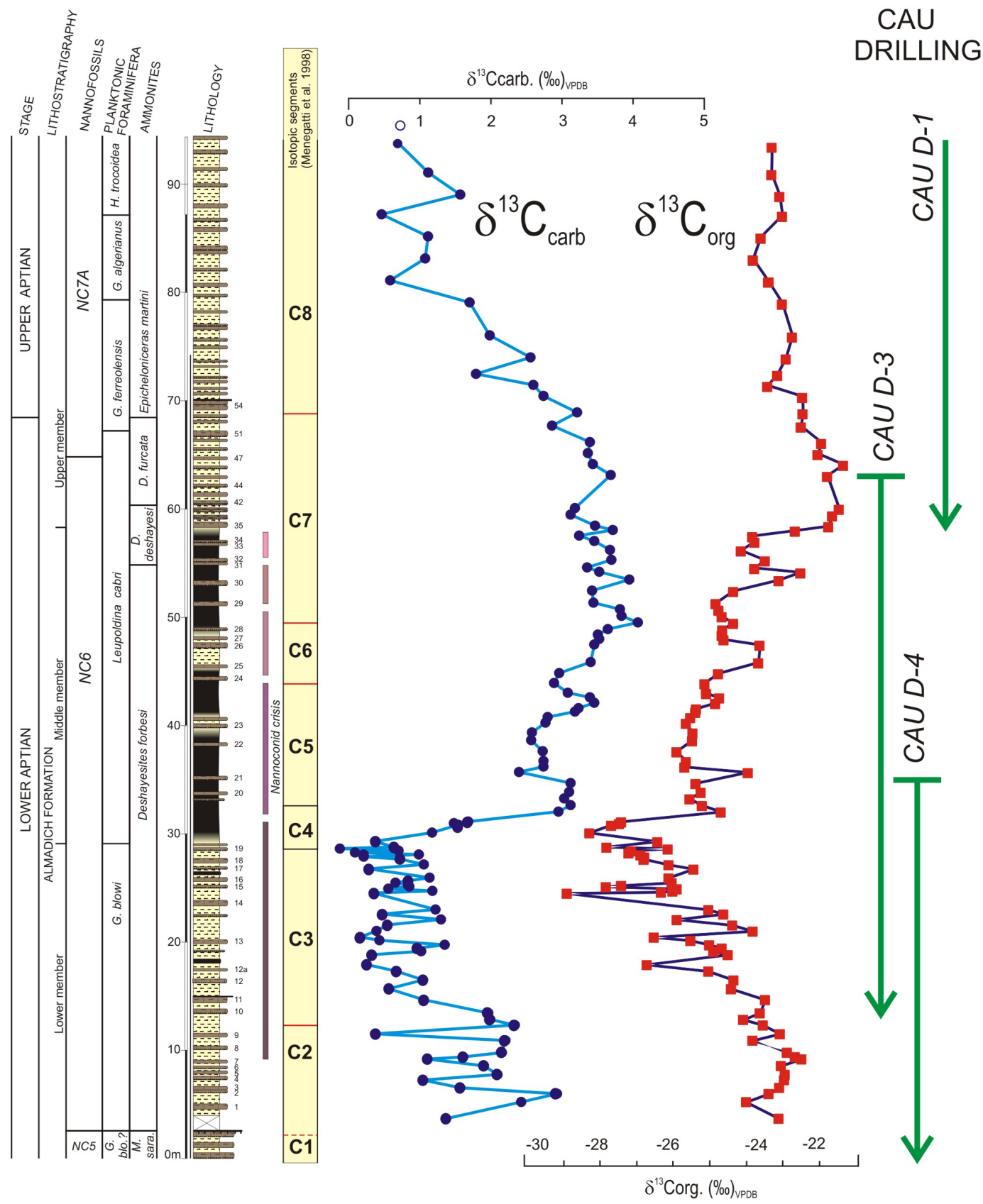

Figure 3. Stratigraphy of the Cau section: lithostratigraphy, biozones, and bioevents together with bulk carbonate (dark blue circles) and total organic matter stable carbon isotopes (red squares) (modified from Naafs et al., 2016). Isotope segments according to Menegatti et al. (1998). The parts of the succession recovered by each of the three drillings are shown to the right.

of this contribution form part of a new multidisciplinary research project focused on the study of the early Aptian in the Betic Cordillera. The project has been financed by the Spanish government.

According to the orientation of the strata in the Cau area, three drillings were carried out, located as shown in Fig. 2. The respective drilling depth reached: D-1 (56 m), D$3(59 \mathrm{~m})$ and D-4 (39 m). D-2 has not been drilled yet; we wait to confirm in the laboratory the overlap between D-1 and D-3. A total of $154 \mathrm{~m}$ of core have been obtained from the $90 \mathrm{~m}$ thick Almadich Formation, with a recovery of almost $100 \%$. The parts of the Cau succession cut by the D-1 to D-4 drillings are shown schematically in Fig. 3.

Outcrop biostratigraphic data from calcareous nannofossils, ammonites and planktonic foraminifera (Aguado et al., 1999; de Gea et al., 2003; de Gea, 2004) indicate that the 


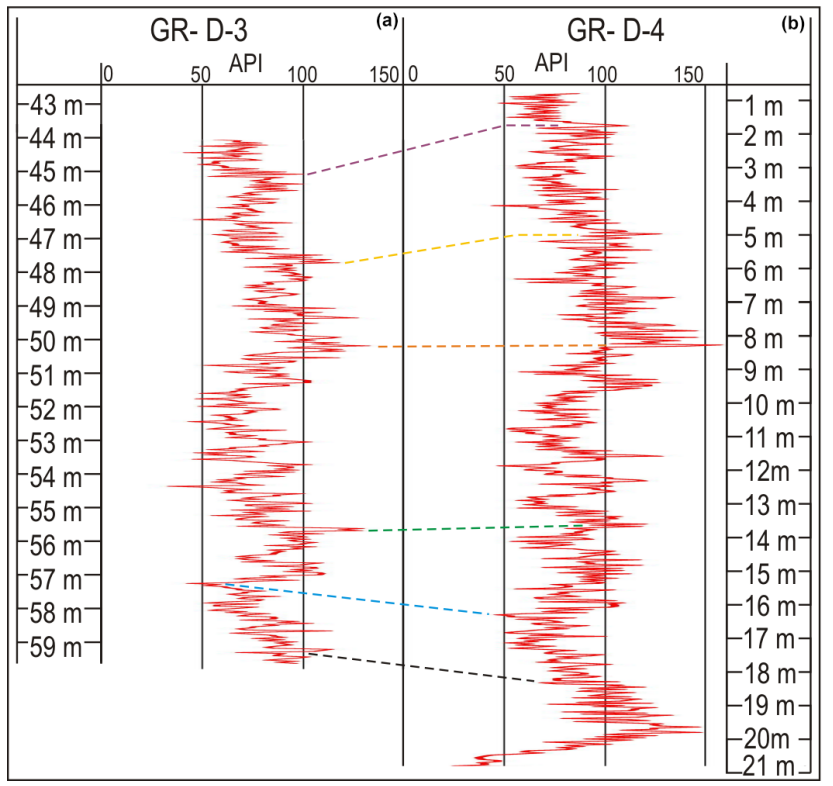

Figure 4: Correlation of gamma-ray logs from the (a) D-3 (metre 44 downwards) and and (b) D-4 (metre 1-21) drillings.

D-1 drilling cuts through upper Aptian sedimentary rocks that correspond to the NC7A calcareous nannofossil zone (Fig. 3). The D-3 and D-4 drillings cut through lower Aptian marly limestones and marls, the top of D-3 being placed in the upper part of $L$. cabri zone of planktonic foraminifera (uppermost part of the lower Aptian), while the D-4 cuts sedimentary rocks attributed to the lowermost part of the $L$. cabri and Globigerinelloides blowi zones. The deepest part of D-4 is late Barremian (NC5 zone) in age.

Initial correlation of the three cores is based on direct core observation and geophysical log profiles of the boreholes, including the gamma-ray log shown in Fig. 4. This figure shows the correlation of drillings D-3 and D-4, from metre 44 of D-3 downcore. In that way we have got a double core sampling of most of the record of OAE1a sediments (Fig. 4).

Figure 5 shows some examples of sliced cores with different lithofacies types, from massive and laminated to deeply bioturbated facies. The colour is dark grey, except for the heavily bioturbated intervals where a lighter grey colour is apparent.

\section{Objectives}

The drilling of the Cau succession aims to provide material to further document the record of OAE1a, and to advance knowledge of the environmental and biotic changes that occurred during this global event. The first objective is to undertake detailed description and sampling of the cores, in order to obtain sedimentological information. The C- and Oisotope stratigraphy will be obtained at a more detailed resolution than is currently available. This will serve as a basis to

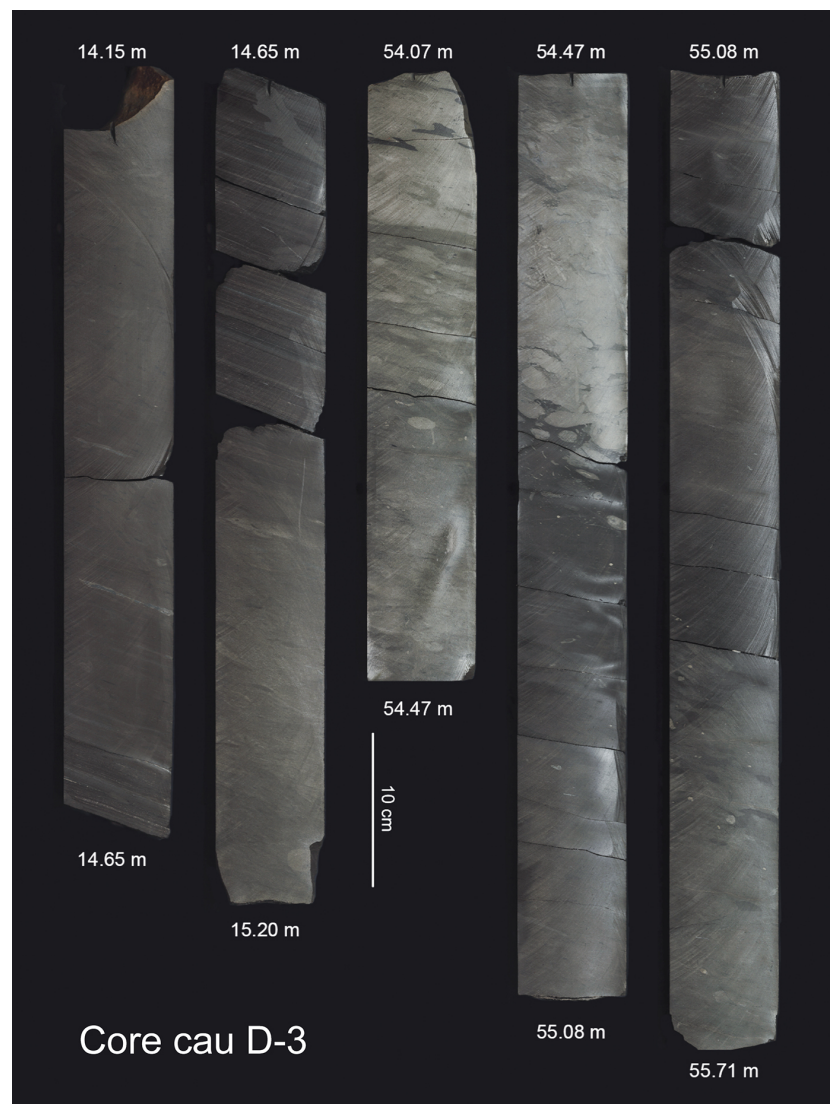

Figure 5. Massive and laminated, lightly bioturbated, facies of D3 core between 14.15 and $15.20 \mathrm{~m}$ depth, and bioturbated facies of D-3 core between 54.07 and $55.71 \mathrm{~m}$.

refine the correlation between the three cores and, most importantly, will provide a reference to analyse the perturbation of the global carbon cycle that occurred across the OAE1a. It will also enable comparison and correlation with other published records from sections worldwide, including those at Cismon (Menegatti et al., 1998; Erba et al., 1999), La Bédoule (Lorenzen et al., 2013), in the Basque Basin (Najarro et al., 2011; Millán et al., 2011), in the Pacific (Dumitrescu et al., 2006), and from the Boreal realm (Mutterlose et al., 2014).

In order to establish a more accurate age model than presently available, which is based on integrated biostratigraphy (Aguado et al., 1999; de Gea et al., 2003; MorenoBedmar et al., 2012), a cyclostratigraphy study is planned that will use the geophysical and geochemical time series. A quantitative nannofossil study will help to constrain the biostratigraphy, and will also analyse the environmental and biotic changes recorded by this fossil group, especially the nannoconid crisis. Additionally, we will address the relative roles of productivity and anoxia in the deposition of organic matter, which will be approached using a combination of geochemical (elemental and organic) and biotic (calcareous nannofossils, planktonic foraminifera, dinoflagellate cysts, 
among others) studies. Other environmental proxies to be considered are those related to $p \mathrm{CO}_{2}$ and palaeotemperature reconstructions, volcanic activity and environmental changes in marine and terrestrial environments, including trace element geochemistry, biomarkers and clay mineralogy. The development of a set of multiple proxies from the same section within an accurate age model at a high stratigraphic resolution, will be crucial in order to advance our knowledge of the major episode of accelerated global environmental change (Föllmi, 2012) that occurred during the early Aptian.

\section{Data availability}

Previous and supplementary information supporting this research is available in tables, graphics, figures, pictures and the appendices of the references cited as well as in the online version of them.

Acknowledgements. The authors wish to express special thanks to the municipality of Llíber (Alicante) and its mayor, D. José Juan Reus, who provided us with all kinds of facilities for carrying out the drilling. Javier Jáimez and Emilio Peñalver, the two technicians who conducted the drilling are also acknowledged.

This work has been funded by the Spanish Government (research project CGL2014-55274-P).

Edited by: T. Wiersberg

Reviewed by: S. Flögel and one anonymous referee

\section{References}

Aguado, R., Castro, J. M., Company, M., and de Gea, G. A.: Aptian bioevents - an integrated biostratigraphic analysis of the Almadich Formation, Inner Prebetic Domain, SE Spain, Cret. Res., 20, 663-683, doi:10.1006/cres.1999.0176, 1999.

Arthur, M. A., Dean, W. E., and Schlanger, S. O.: Variations in the global carbon cycle during the Cretaceous related to climate, volcanism, and changes in atmospheric $\mathrm{CO}_{2}$, in: The Carbon Cycle and Atmospheric $\mathrm{CO}_{2}$ : Natural Variations Archaean to Present, Geophys. Monogr. Ser., vol. 32, edited by: Sundquist, E. T. and Broecker, W. E., 504-529, AGU, Washington, D.C., 1985.

Arthur, M. A., Jenkyns, H. C., Brumsack, H., and Schlanger, S. O.: Stratigraphy, geochemistry, and paleoceanography of organic carbon-rich Cretaceous sequences, in: Cretaceous Resources, Events and Rhythms, edited by: Ginsburg, R. N. and Beaudoin, B. Kluwer Academic, Dordrecht, 75-119, NATO AS1 Series C, 304, 1990

Beerling, D. J. and Royer, D. L.: Fossil plants as indicators of the Phanerozoic global carbon cycle, Annu. Rev. Earth Pl. Sc., 30, 527-556, 2002.

Castro, J. M., de Gea, G. A., Ruiz-Ortiz, P. A., and Nieto, L. M.: Development of carbonate platforms on an extensional (rifted) margin. The Valanginian-Albian record of the Prebetic of Alicante (SE Spain), Cret. Res., 29, 848-860, doi:10.1016/j.cretres.2008.05.012, 2008. de Gea, G. A.: Bioestratigrafía y eventos del Cretácico Inferior en las Zonas Externas de la Cordillera Bética, Servicio de Publicaciones de la Universidad de Jaén, Jaén, 658 pp., 2004.

de Gea, G. A., Castro, J. M., Aguado, R., Company, M., and Ruiz-Ortiz, P. A.: Lower Aptian carbon-isotope stratigraphy from a distal carbonate shelf setting. The Cau section, Prebetic Zone, SE of Spain, Palaeogeogr. Palaeocl., 200, 207-219, doi:10.1016/S0031-0182(03)00451-6, 2003.

Dumitrescu, M., Brassell, S. C., Schouten, S., Hopmans, E. C., and Sinninghe-Damste, J. S.: Instability in tropical Pacific seasurface temperatures during the early Aptian, Geology, 34, 833836, 2006.

Erba, E.: Nannofossils and superplumes: the early Aptian "nannoconid crisis", Paleoceanography, 9, 483-501, doi:10.1029/94PA00258, 1994.

Erba, E., Bottini, C., Weissert, H., and Keller, C. E.: Calcareous nannoplankton response to surface-water acidification around Oceanic Anoxic Event 1a, Science, 329, 428-432, doi:10.1126/science.1188886, 2010.

Erba, E., Channell, J. E. T., Claps, M., Jones, C., Larson, R. L., Opdyke, B., Premoli Silva, I., Riva, A., Salvini, G., and Torricelli, S.: Integrated stratigraphy of the Cismon Apticore (Southern Alps, Italy): a reference section for the Barremian-Aptian interval at low latitudes, J. Foramin. Res., 29, 371-391, 1999.

Erba, E., Duncan, R. A., Bottini, C., Tiraboschi, D., Weissert, H., Jenkyns, H. C., and Malinverno, A.: Environmental consequences of Ontong Java Plateau and Kerguelen Plateau volcanism, Spec. Paper Geol. Soc. America, 511, 271-303, doi:10.1130/2015.2511(15), 2015.

Flögel, S., Kuhnt, W., and Moullade, M.: Drilling of Early Cretaceous Oceanic Anoxic Event 1a in Southern France, Sci. Dril., 9, 20-22, doi:10.2204/iodp.sd.9.03.2010, 2010.

Föllmi, K. B.: Early Cretaceous life, climate and anoxia, Cret. Res., 35, 230-257, doi:10.1016/j.cretres.2011.12.005, 2012.

Jenkyns, H. C.: Cretaceous anoxic events: from continents to oceans, J. Geol. Soc. London, 137, 171-188, 1980.

Jenkyns, H. C.: Geochemistry of oceanic anoxic events, Geochem. Geophy. Geosy., 11, Q03004, doi:10.1029/2009GC002788, 2010.

Larson, R. L. and Erba, E.: Onset of the mid-Cretaceous greenhouse in the Barremian-Aptian: igneous events and the biological, sedimentary and geochemical responses, Paleoceanography, 14, 663-678, doi:10.1029/1999PA900040, 1999.

Lorenzen, J., Kuhnt, W., Holbourn, A., Flögel, S., Moullade, M., and Tronchetti, G.: A new sediment core from the Bedoulian (Lower Aptian) stratotype at Roquefort-La Bédoule, SE France, Cret. Res., 39, 6-16, doi:10.1016/j.cretres.2012.03.019, 2013.

Menegatti, A. P., Weissert, H., Brown, R. S., Tyson, R. V., Farrimond, P., Strasser, A., and Caron, M.: Highresolution $\delta^{13} \mathrm{C}$ stratigraphy through the early Aptian "Livello Selli" of the Alpine Tethys, Paleoceanography, 13, 530-545, doi:10.1029/98PA01793, 1998.

Millán, M. I., Weissert, H. J., Owen, H., Fernández-Mendiola, P. A., and García-Mondéjar, J.: The Madotz Urgonian platform (Aralar, northern Spain): Paleoecological changes in response to Early Aptian global environmental events, Palaeogeogr. Palaeocl., 312, 167-180, doi:10.1016/j.palaeo.2011.10.005, 2011.

Moreno-Bedmar, J. A., Company, M., Sandoval, J., Tavera, J. M., Bover-Arnal, T., Salas, R., Delanoy, G., Maurrasse, F.J.- 
M.R., and Martínez, R.: Lower Aptian ammonite and carbon isotope stratigraphy in the eastern Prebetic Domain (Betic Cordillera, southeastern Spain), Geol. Acta, 1-0, 333-350, doi:10.1344/105.000001752, 2012.

Mutterlose, J., Bottini, C., Schouten, S., and Sinninghe Damsté, J. S.: High sea-surface temperatures during the early Aptian Oceanic Anoxic Event 1a in the Boreal Realm, Geology, 42, 439-442, 2014.

Naafs, B. D. A., Castro, J. M., de Gea, G. A., Quijano, M. L., Schmidt, D. N., and Pancost, R. D.: Gradual and sustained carbon dioxide release during Aptian Oceanic Anoxic Event 1a, Nature Geosci. Lett., 9, 135-139, doi:10.1038/NGEO2627, 2016.

Najarro, M., Rosales, I., Moreno-Bedmar, J. A., Gea, G. A. de, Barrón, E., Company, M., and Delanoy, G.: High-resolution chemoand biostratigraphic records of the Early Aptian oceanic anoxic event in Cantabria (N Spain): Palaeoceanographic and palaeoclimatic implications, Palaeogeogr. Palaeocl., 299, 137-158, 2011.
Quijano, M. L., Castro, J. M., Pancost, R. D., de Gea, G. A., Najarro, M., Aguado, R., Rosales, I., and Martín-Chivelet, J.: Organic geochemistry, stable isotopes, and facies analysis of the Early Aptian OAE - New records from Spain (Western Tethys), Palaeogeogr. Palaeocl., 365-366, 276-293, 2012.

Schlanger, S. O. and Jenkyns, H. C.: Cretaceous oceanic anoxic events: causes and consequences, Geol. Mijnb., 55, 179-184, 1976.

Tejada, M. L., Suzuki, K., Kuroda, J., Coccioni, R., Mahoney, J. J., Ohkouchi, N., Sakamoto, N., and Tatsumi, Y.: Ontong Java Plateau eruption as a trigger for the early Aptian oceanic anoxic event, Geology, 37, 855-858, doi:10.1130/G25763A.1, 2009. 